\title{
PERFORMANCE OF INTERCROPPING GROUNDNUT WITH SESAME
}

\author{
M. A. H. Khan, N. Sultana, S. Akhtar, N. Akter and M. S. Zaman \\ On-Farm Research Division \\ Bangladesh Agricultural Research Institute, Mymensingh, Bangladesh \\ Corresponding author: helim1367@gmail.com
}

Key words: Intercropping, productivity, equivalent yield, land equivalent ratio and harvest index

\begin{abstract}
The experiment was carried out at the farmers' field of On-Farm Research Division, Bangladesh Agricultural Research Institute (BARI), Mymensingh during two consecutive years 2015 and 2016 to find out the suitable intercropping system for increasing crop productivity and profitability of groundnut with sesame intercropping system. The treatments were $T_{1}=$ sole groundnut, $T_{2}=$ sole sesame, $T_{3}=$ Two rows of groundnut in between paired rows of sesame and $T_{4}=$ Three rows of groundnut in between paired rows of sesame. Treatments were arranged in a randomized complete block design with six dispersed replications. Between intercropped treatments, three rows of groundnut within paired rows of sesame showed higher sesame equivalent yield $\left(2.33\right.$ tha $\left.^{-1}\right)$ and groundnut equivalent yield $\left(2.14\right.$ tha $\left.^{-1}\right)$ which provided the yield advantages of 108 and $32 \%$ over the respective sole crops. The highest land equivalent ratio (1.64), gross return (Tk 1,28,350 ha-1) and benefit cost ratio (2.15) were also achieved in three rows of groundnut within paired rows of sesame compared to other intercropping and sole cropping systems. The result showed that three rows of groundnut in between paired rows of sesame is found most productive and profitable than sole sesame or sole groundnut for maximum profit in Mymensingh region
\end{abstract}

\section{Introduction}

Bangladesh is an agriculture based country and about $14.75 \%$ gross domestic product (GDP) comes from agriculture in Bangladesh (AIS, 2017). The main challenge of the new millennium is to increase yield of per unit area by at least $50 \%$ through manipulating the limited land resource. Sesame (Sesamum indicum L.) is an important oilseed crop ranked second-in terms of acreage (38057 ha) of land and produces 36,000 metric tons of sesame seeds with an average yield of $860 \mathrm{~kg} \mathrm{ha}^{-1}$ (BBS, 2015). It can be cultivated both in kharif and rabi seasons. Sesame is a drought resistant crop. It cannot tolerate water logging or excess moisture in the field. Seeds contain 42-45\% oil and $20 \%$ protein (Mondal and Wahhab, 2001). The cultivation of sesame is drastically declining due to widely increasing of rice, maize and mungbean cultivation in kharif-I season. Moreover, sesame competes with jute and different vegetables in the season. Intercropping plays an important role in increasing the productivity and stability of yield in order to improve resource utilization and environmental factors (Alizadeh et al., 2010). Research in different countries reveals that intercropping has several benefits to the farmers including reduction in farm inputs, diversification of diet, addition of cash crops, increased labour utilization efficiency, reduced risk of crop failure, more efficient use of water resources, nutrients and reduced problems caused by pests, diseases and weeds (Awal et al., 2006). So, intercropping of sesame with groundnut could help to retain oilseed crops and ensure highest productivity per unit area as well as supply of oil . Groundnut (Arachis hypogaea L.) is the third 
Khan et al.

most important legume crop in Bangladesh which grown on 31,579 ha of land and produces 56713 metric tons of nut with an average yield of $1.79 \mathrm{t} \mathrm{ha}^{-1}$ (BBS, 2015). Recently the area of groundnut is being decreased due to the competition with rabi crops like wheat, potato, boro rice and mustard (Alom et. al., 2009). Moreover, most of the char land of Bangladesh become inundated in kharif season which also one of the causes the decline of groundnut production area. Some experimental evidences showed that in the sesame field groundnut can be grown as intercrop. Groundnut var. BARI Chinabadam-8 is short in stature and suitable for early kharif and late kharif planting. Groundnut can withstand excessive rainfall. So, if sesame crop is damaged due to heavy rainfall, groundnut crop will thrive and farmers will not lose their crops fully. The research findings stated that nitrogen fixation in groundnut and the residual benefits through incorporation of stover to subsequent crops were estimated in farmers' fields (Mondal and Wahhab, 2001). Better intercrop production could be achieved with the choice of appropriate crops population density and planting geometry of component crops (Santalla et al., 2001). Groundnut and sesame in intercropping systems may increase their production and profit. In this context, the experiment was conducted to find out the suitable intercrop combination of sesame with groundnut for higher productivity and profitability.

\section{Materials and Methods}

The experiment was carried out at the farmers' field of On-Farm Research Division, Bangladesh Agricultural Research Institute (BARI), Mymensingh during two consecutive years 2015 and 2016 to find out the suitable intercropping system for increasing crop productivity and profitability of groundnut sesame intercropping system. The experimental soil was sandy loam to silty loam of the medium highland having pH 6.2 to 6.5 under the Agro-ecological Zone-9 (AEZ-9). The treatments were as $T_{1}=$ sole groundnut, $T_{2}=$ sole sesame, $T_{3}=$ Two rows of groundnut in between paired rows of sesame and $T_{4}=$ Three rows of groundnut in between paired rows of sesame. Groundnut var. BARI Chinabadam- 8 and Sesame var. BARI Til- 4 were used. The experiment was laid out in a randomized complete block design with six dispersed replications. The unit plot size was $8.0 \mathrm{~m} \times 5.0 \mathrm{~m}$. The seeds of sesame were sown in $30 \mathrm{~cm}$ apart paired rows and $75 \mathrm{~cm}$ between two pairs with $5 \mathrm{~cm}$ between the plants. The spacing maintained for sole groundnut was $25 \mathrm{~cm} \times 10 \mathrm{~cm}$ for intercropping system, the plant population of sesame plots remained same as sole plot but it varied for groundnut. The seed germination of both crops was 95 percent. Seeds of both crops were sown on 07 to 14 March 2015 and 2016. Fertilizers were applied at the rate of $15-32-42-27-2-2 \mathrm{~kg} \mathrm{NPKSZnB} \mathrm{ha}^{-1}$ in the form of urea, triple super phosphate, muriate of potash, gypsum, zinc sulphate and boric acid, respectively (Mondal and Wahhab, 2001). All fertilizers were applied as basal during final land preparation by broadcasting method. Additional $20 \mathrm{~kg} \mathrm{ha}^{-1}$ of urea applied as top dressed in between two rows of sesame at 25-30 DAS. Thinning was done after 15-20 days of seed germination in both the years. Mulching and hand weeding were done as and when necessary to keep the field reasonable weed free. Dursban $2 \mathrm{ml} \mathrm{L}^{-1}$ water was sprayed at $15-20$ days intervals as precautionary measure against insects attack. Dithane $\mathrm{M}-452 \mathrm{~g} \mathrm{~L}^{-1}$ water was sprayed at 15 days intervals at the later stages of groundnut as precautionary measure from prevalence of disease. Seed, pod and straw yields at harvest were converted into tha ${ }^{-1}$ after proper drying. Sesame was harvested on 07-10 June 2015 and 08-12 June 2016 and groundnut on 07-14 July 2015 and 15-21 July 2016 at physiological maturity.. 
Pest and disease incidence: Nitro@ $@ \mathrm{mlL}^{-1}$ water was sprayed twice at 10 days interval for successful controlling the hairy caterpillar and thrips. Stem rot of sesame was observed sporadically in the flowering stage of sesame; Baiting @ $2 \mathrm{gL}^{-1}$ water was sprayed twice at 7 days interval for controlling fungal disease. No other disease and insects infestation was observed during the cropping period. The yield contributing characters of sesame and groundnut were recorded from 10 randomly selected plants in both the years. Harvest index (HI) was calculated as per following equation:

$$
\mathrm{HI}(\%)=\frac{\text { Grain yield }}{\text { Biological yield }} \times 100
$$

Yield of individual crop was converted into equivalent yield on the basis of the prevailing market price of individual crop (Prasad and Srivastava, 1991).

$$
\begin{aligned}
& \text { Sesame equivalent yield }(\mathrm{SEY})=\text { Yield of intercrop sesame }+\frac{\mathrm{Yig} \times \mathrm{Pg}}{\mathrm{Ps}} \text { and } \\
& \text { Groundnut equivalent yield }(\mathrm{GEY})=\text { Yield of intercrop groundnut }+\frac{\mathrm{Yis} \times \mathrm{Ps}}{\mathrm{Pg}}
\end{aligned}
$$

Where, Yig= Yield of intercrop groundnut, $\mathrm{Pg}=$ Price of groundnut, $\mathrm{Ps}=$ Price of sesame and Yis= Yield of intercrop sesame

In intercropping systems, relative yield was quantified by (Jokinen, 1991).

Relative Yield of Sesame (RYs): $\frac{\text { Yis }}{\text { Yss }}$, Relative Yield of Groundnut (RYg): $\frac{Y i g}{Y s g}$ and

Relative yield total (RYT): RYs + RYg,

Where Yss= Yield of sole sesame, Yis= Yield of intercrop sesame, Ysg= Yield of sole groundnut and Yig yield of intercrop groundnut.

On the other hand, land equivalent ratio (LER) was used for measuring the efficiency of intercropping advantages using the resources of environment compared to monoculture. Land equivalent ratio (LER) were calculated by adding the partial LER for each crop and it was calculated by the following formula (Mead and Willey, 1980)

$$
\mathrm{LER}=\frac{\mathrm{Yis}}{\mathrm{Yss}}+\frac{\mathrm{Yig}}{\mathrm{Ysg}}
$$

Where, Yis=Yield of intercrop sesame, Yss=Yield of sole sesame, Yig=Yield of intercrop groundnut and $Y$ sg=Yield of sole groundnut

Pooled analysis was done as because there was no significant difference in yield and yield contributing characters between two years. Data were statistically analyzed using analysis of variance technique with the help of computer package MSTAT-C and mean comparison among the treatments was made by LSD test at 5\% level of significance. 
Khan et al.

\section{Results and Discussion}

Yield and yield attributes of sesame: It was observed that the seed yields of sesame significantly influenced intercropping systems but other yield attributes were not insignificant (Table 1). The highest seed yield (1.12 $\mathrm{t} \mathrm{ha}^{-1}$ ) was recorded from $\mathrm{T}_{2}$ (sole sesame) which was statistically different with $\mathrm{T}_{3}$ (Two rows of groundnut in between paired rows of sesame) and $\mathrm{T}_{4}$ (Three rows of groundnut in between two paired rows of sesame). Lower seed yield $\left(0.89 \mathrm{t} \mathrm{ha}^{-1}\right)$ was obtained from $\mathrm{T}_{3}$ which was statistically significant with other treatments. Higher seed yield of sesame was observed in monoculture compared to intercropping systems might be due to no intercrop competition for light, nutrients, moisture and space. This result corroborates with the findings of Uddin et al., (2003). Sesame gave 13 to $21 \%$ lower yield in intercropping treatments as compared to their corresponding monoculture, though the plant population of sesame was constant regardless of treatment. The seed yield of sesame was reduced probably due to intercrop competition between sesame and groundnut. However, additional yield from groundnut not only compensated the deficit but also gave extra income. This finding is in conformity with Islam et al., (2016). The harvest index (HI) of sesame did not differ by the intercropping systems; it had higher values in $\mathrm{T}_{4}>\mathrm{T}_{3}>\mathrm{T}_{2}$ (Table 1).

Table1. Seed yield, yield attributes and harvest index of sesame under sesame + groundnut intercropping systems in Mymensingh, 2015 and 2016 (Pooled)

\begin{tabular}{ccccccc}
\hline Treatments & $\begin{array}{c}\text { Plant } \\
\text { height }(\mathrm{cm})\end{array}$ & $\begin{array}{c}\text { Branch } \\
\text { plant }^{-1} \text { (no.) }\end{array}$ & $\begin{array}{c}\text { Capsules plant } \\
\text { (no.) }\end{array}$ & $\begin{array}{c}1000- \\
\text { seed } \\
\text { wt. (g) }\end{array}$ & $\begin{array}{c}\text { Seed yield } \\
\left(\mathrm{t} \mathrm{ha}^{-1}\right)\end{array}$ & $\begin{array}{c}\text { Harvest } \\
\text { index } \\
(\%)\end{array}$ \\
\hline $\mathrm{T}_{2}$ & 149.0 & 5.1 & 86.2 & 3.2 & 1.12 & 37 \\
$\mathrm{~T}_{3}$ & 150.4 & 5.1 & 89.8 & 3.4 & 0.89 & 50 \\
$\mathrm{~T}_{4}$ & 151.8 & 5.0 & 90.8 & 3.4 & 0.97 & 51 \\
\hline LSD (0.05) & $\mathrm{ns}$ & $\mathrm{ns}$ & $\mathrm{ns}$ & $\mathrm{ns}$ & 0.20 & $\mathrm{~ns}$ \\
$\mathrm{CV}(\%)$ & 5.11 & 8.73 & 5.32 & 7.44 & 6.42 & - \\
\hline
\end{tabular}

Note:- $T_{2}=$ Sole sesame, $T_{3}=$ Two rows of groundnut in between paired rows of sesame and $T_{4}=$ Three rows of groundnut in between paired rows of sesame.

Yield and yield attributes of groundnut: The variation was found in branches plant ${ }^{-1}$, kernel plant $^{-1}$, shelling percent and nut yield hectare while plant height and 100-kernel weight were found insignificant (Table 2). The highest nut yield was recorded in $T_{1}$ (sole groundnut) mainly due to the higher kernel number plant ${ }^{-1}, 100$-kernel weight and shelling percent of groundnut. The nut yield of groundnut was reduced 23 to $46 \%$ in intercropping system than sole crop of groundnut. This result corroborates with the findings of Razzaque et al., (2007) who reported that less groundnut yield was obtained from intercropping system than sole crop due to shading effect of chilli on groundnut. In $\mathrm{T}_{4}$ (Three rows of groundnut in between paired rows of sesame) had higher nut yield due to paired rows planting system of sesame fovoured the growth of intercropped groundnut and judicious use of growth resources compared to others. These results are in conformity with the findings of Islam et al., (2006). Higher harvest index (HI) of groundnut was slightly higher in $\mathrm{T}_{4}$ (Three rows of groundnut in between two paired rows of sesame) possibly owing to use of more assimilates to the reproductive organs (Table 2). 
Performance of Intercropping Groundnut with Sesame

Table 2. Nut yield, yield attributes and harvest index of groundnut under sesame + groundnut intercropping systems in Mymensingh, 2015 and 2016 (Pooled)

\begin{tabular}{cccccccc}
\hline Treatments & $\begin{array}{c}\text { Plant } \\
\text { height } \\
(\mathrm{cm})\end{array}$ & $\begin{array}{c}\text { Branch } \\
\text { plant }^{-1} \\
(\text { no. })\end{array}$ & $\begin{array}{c}\text { Kernel } \\
\text { plant }^{-1} \\
(\text { no. })\end{array}$ & $\begin{array}{c}\text { 100- kernel } \\
\text { wt. } \\
(\mathrm{g})\end{array}$ & $\begin{array}{c}\text { Shelling } \\
(\%)\end{array}$ & $\begin{array}{c}\text { Nut yield } \\
\left(\mathrm{t} \mathrm{ha}^{-1}\right)\end{array}$ & $\begin{array}{c}\text { Harvest } \\
\text { index } \\
(\%)\end{array}$ \\
\hline $\mathrm{T}_{1}$ & 38.2 & 7.8 & 17.2 & 90.2 & 66.4 & 1.62 & 52 \\
& & & & & & & \\
$\mathrm{~T}_{3}$ & 35.0 & 6.8 & 13.2 & 88.4 & 64.4 & 0.88 & 48 \\
$\mathrm{~T}_{4}$ & 36.0 & 6.6 & 14.2 & 89.6 & 66.0 & 1.25 & 53 \\
\hline LSD (0.05) & $\mathrm{ns}$ & 1.01 & 2.14 & $\mathrm{~ns}$ & 1.74 & 0.32 & - \\
$\mathrm{CV}(\%)$ & 6.77 & 9.84 & 9.90 & 5.32 & 8.33 & 7.62 & - \\
\hline
\end{tabular}

Note:- $\mathrm{T}_{1}=$ Sole groundnut, $\mathrm{T}_{3}=$ Two rows of groundnut in between two paired rows of sesame and $\mathrm{T}_{4}=$ Three rows of groundnut in between two paired rows of sesame.

Equivalent yield and relative yield: All the intercropping systems gave higher sesame and groundnut equivalent yield than that of their corresponding sole crops (Table 3). The highest sesame equivalent yield $\left(2.33 \mathrm{t} \mathrm{ha}^{-1}\right)$ as well as groundnut equivalent yield $\left(2.14 \mathrm{t} \mathrm{ha} \mathrm{H}^{-1}\right)$ were recorded from $\mathrm{T}_{4}$ (three rows of groundnut in between two paired rows of sesame) which covered the yield advantages of 133 and $37 \%$ over their respective sole crops. Such yield advantage might be due to combined yield of both the crops. The results are in agreement with the finding of Islam et. al., (2016) who reported that highest turmeric equivalent yield was found from turmeric $(100 \%)+3$ rows of sesame in between turmeric lines. The partial relative yields of intercropped sesame varied from 0.79 to 0.87 and intercropped groundnut ranged from 0.54 to 0.77 (Table 3). Sesame yield was reduced (13 to $21 \%$ ) and groundnut yield reduced (23 to $46 \%$ ) among the intercropping system. The yield was reduced due to lower plant population. The result showed that $T_{4}$ was well accommodative in competitiveness in sesame + groundnut intercropping system (Table 3).

Land equivalent ratio (LER): The land equivalent ratio (LER) was used to assess the performance of an intercrop relative to the corresponding sole crop (Mead and Willey, 1980). The highest LER value (1.55) was obtained from $\mathrm{T}_{4}$ (three rows of groundnut in between two paired row of sesame) which indicated the superiority of intercropping over monoculture (Table 3). It also expressed that by intercropping groundnut with sesame, a farmer can produce 1.25 tons groundnut and 0.97 tons sesame in one hectare of land instead of cultivate those separately as sole crop.

Table 3. Equivalent yields, relative yields and land equivalent ratio of sesame + groundnut combinations in Mymensingh, 2015 and 2016 (Pooled)

\begin{tabular}{|c|c|c|c|c|c|}
\hline \multirow[t]{2}{*}{ Treatments } & \multirow{2}{*}{$\begin{array}{c}\text { Sesame } \\
\text { equivalent yield } \\
\text { (t ha-1) }\end{array}$} & \multirow{2}{*}{$\begin{array}{l}\text { Groundnut } \\
\text { equivalent } \\
\text { yield }\left(\mathrm{t} \mathrm{ha}^{-1}\right)\end{array}$} & \multicolumn{2}{|c|}{ Partial relative yield ( $\mathrm{t} \mathrm{ha}^{-1}$ ) } & \multirow{2}{*}{$\begin{array}{c}\text { Land } \\
\text { equivalent } \\
\text { ratio (LER) }\end{array}$} \\
\hline & & & Sesame & Groundnut & \\
\hline $\mathrm{T}_{1}$ & 1.77 & 1.62 & - & - & 1.00 \\
\hline $\mathrm{T}_{2}$ & 1.12 & 1.03 & - & - & 1.00 \\
\hline $\mathrm{T}_{3}$ & 1.85 & 1.70 & 0.79 & 0.54 & 1.33 \\
\hline $\mathrm{T}_{4}$ & 2.33 & 2.14 & 0.87 & 0.77 & 1.64 \\
\hline
\end{tabular}

Note:- $\mathrm{T}_{1}=$ Sole groundnut, $\mathrm{T}_{2}=$ Sole sesame, $\mathrm{T}_{3}=$ Two rows of groundnut in between paired rows of sesame and $\mathrm{T}_{4}=$ Three rows of groundnut in between paired rows of sesame. 
Khan et al.

Economic return of intercropping groundnut with sesame: On the basis of two years average result, the highest monetary return $(T k .68,535)$ was observed in $T_{4}$ (three rows of groundnut in between two paired rows of sesame) which gave an additional income of Tk. 27,300 over sole crop of groundnut and Tk. 54,735 over sole crop of sesame (Table 4). Both intercrop combination gave higher monetary advantages over sole groundnut and sesame. The highest $\mathrm{BCR}$ (2.15) was found in $\mathrm{T}_{4}$ (three rows of groundnut in between two paired rows of sesame) over other treatments. These results are in agreement with the findings of Islam et al. (2016) who stated that turmeric $(100 \%)+3$ rows of sesame $(100 \%)$ in between turmeric lines intercropping system gave higher additional income and $\mathrm{BCR}$ over the sole crop of turmeric.

Table 4. Economics of intercropping sesame with groundnut in Mymensingh, 2015 and 2016 (average of two years)

\begin{tabular}{lcccc}
\hline Treatments & $\begin{array}{c}\text { Gross return } \\
\left(\text { Tk. ha }^{-1}\right)\end{array}$ & $\begin{array}{c}\text { Total cost } \\
\left(\text { Tk. ha }^{-1}\right)\end{array}$ & $\begin{array}{c}\text { Gross margin } \\
\left(\text { Tk. ha }^{-1}\right)\end{array}$ & BCR \\
\hline $\mathrm{T}_{1}$ & 97200 & 55965 & 41235 & 1.74 \\
$\mathrm{~T}_{2}$ & 61600 & 47800 & 13800 & 1.29 \\
$\mathrm{~T}_{3}$ & 101750 & 57390 & 44360 & 1.77 \\
$\mathrm{~T}_{4}$ & 128350 & 59815 & 68535 & 2.15 \\
\hline
\end{tabular}

Market price: Groundnut $=$ Tk. $60 \mathrm{~kg}^{-1}$ and Sesame $=$ Tk. $55 \mathrm{~kg}^{-1}$

\section{Conclusion}

Two years average result indicating that intercropping groundnut with sesame gave maximum productivity as well as economic return than monoculture of component crops. The equivalent yields, relative yields, land equivalent ratio (LER) values and economic return were found highest in $T_{4}$ (three rows of groundnut in between two paired rows of sesame) in groundnut + sesame intercropping system. Thus it could be concluded that three rows of groundnut in between paired rows of sesame intercropping system could be adopted for better productivity with maximum profit for the farmers of Mymensingh regions instead of sole crops.

\section{References}

AIS (Agricultural Information Service). 2017. Krishi Diary. Agril. Infor. Service, Khamarbari, Farmgate, Dhaka 1216. p 2.

Alizadeh, Y., A. Koocheki and M. Nassiri Mahallati. 2010. Yield, yield components and potential weed control of intercropping bean (Phaseolus vulgaris L.) with sweet basil (Ocimum basilicum L.). Iranian J. of Field Crops Res. 7 (2): 541-553.

Alom, M. S., N. K. Paul and M. A. Quayyum. 2009. Performance of different hybrid maize (Zea mays L.) varieties under intercropping systems with groundnut (Arachis hypogaea L.). Bangladesh J. Agril. Sci. 34 (4):585-595.

Awal, M. A., H. Koshi and T. Ikeda. 2006. Radiation interception and use by maize/peanut intercrop canopy. Agricultural and Forest Meteorology. 139: 74-83.

BBS (Bangladesh Bureau of Statistics). 2015. Year Book of Agricultural Statistics of Bangladesh. Statistics and Informatics Division, Ministry of Planning, Government of the People's Republic of Bangladesh, Dhaka. p 40. 
Islam, M. N., M. M. Haque and A. Hamid. 2006. Planting arrangement and population density effects on the physiology attributes and productivity of maize-bush bean intercropping system. Bangladesh J. Agril. Res. 31(3):353-364.

Islam, M. R., M. S. H. Molla and M. A. K. Mian. 2016. Productivity and profitability of intercropping sesame with turmeric at marginal farmers level of Bangladesh. SAARC J. Agri., 14(1): 47-58.

Jokinen, K. 1991. Yield and competition in barley variety mixtures. J. Agric. Sci. 17 (1):99-102.

Mead, R. and R. W. Willey. 1980. The concept of land equivalent ratio and advantages in yields for intercropping. Exp. Agric. 16: 217-228.

Mondal, M. R. I. and M A. Wahhab. 2001. Production technology of oil crops, Oilseed Research Centre, Bangladesh Agricultural Research Institute, Joydebpur, Gazipur-1701.

Prasad, K., and R. C. Srivastava. 1991. Pigeon pea (Cajanus cajan) and (Glycine max) intercropping system under rainfed situation. Indian J. Agric. Sci. 61: 243-246.

Razzaque, M. A., S. Rafiquzzaman, M. M. Bazzaz, M. A. Ali and M. M. R. Talukdar. 2007. Study on the intercropping groundnut with chilli at different plant populations. . Bangladesh J. Agril. Res. 32(1):37-43.

Santalla, M., A. P. Rodino, P. A. Casquero and A. M. De Ron. 2001. Interactions of bush bean intercropped with field and sweet maize. European J. Agron. 15: 185-196.

Uddin, M. S., M. J. Rahman, S. A. Begum and M. R. Ali. 2003. Intercropping of maize with soybean in saline area under rainfed condition. . Bangladesh J. Agril. Res. 28(3):451-455. 